\title{
Automotive Engineering Drawing Learning: Effective Online Learning Using Autocad Application
}

\author{
G Farid Mutohhari ${ }^{1 *}$, Putu Sudira ${ }^{2}$, Muhammad Nurtanto ${ }^{3}$ \\ 1,2 Postgraduate Program of Technology and Vocational Education, Yogyakarta State University, Yogyakarta, Indonesia \\ ${ }^{3}$ Department of Mechanical Engineering Education, Universitas Sultan Ageng Tirtayasa, Banten, Indonesia
}

\section{A R T I C L E I N F O}

Article history:

Received March 19, 2021

Revised April 05, 2021

Accepted May 03, 2021

Available online May 25, 2021

\section{Kata Kunci:}

Pembelajaran Daring, Gambar Teknik Otomotif Aplikasi Autocad

\section{Keywords:}

Online Learning, Automotive Engineering Drawing, Autocad Application

\section{A B S T R A C T}

\begin{abstract}
A B S T R A K
Hasil belajar tidak memuaskan dan motivasi belajar siswa rendah. Akibatnya, siswa tidak dapat menguasai sepenuhnya kompetensi gambar teknik otomotif yang merupakan hasil belajar. Penelitian ini bertujuan untuk menganalisis pengaruh penggunaan software autocad untuk meningkatkan hasil belajar daring gambar teknik otomotif siswa. Penelitian kuasi eksperimen menggunakan design pretestposttest control grup. Seluruh siswa kelas X program keahlian teknik dan bisnis sepeda motor dalam dua SMK menjadi populasi dalam penelitian ini. Sampel yang digunakan dalam penelitian ini berjumlah 112 siswa yang terbagi dalam 4 kelas di dua SMK. Teknik pengumpulan data dilakukan menggunakan tes dengan instrument tes objektif pilihan ganda dan lembar kerja gambar. Data yang terkumpul dianalisis menggunakan statistik deskripsif dan statistik inferensial dengan uji t. Hasil uji $t$ diperoleh $t_{\text {hitung }}=9,703$ dengan tabel pada taraf signifikansi $5 \%=1,986$. Hasil tersebut menunjukkan nilai thitung $>t_{\text {tabel, }}$ sehingga menerima $H_{a}$ dan menolak $H_{0}$. Dengan demikian disimpulkan bahwa penggunaan software autocad dalam pembelajaran daring gambar teknik otomotif berpengaruh signifikan untuk meningkatkan hasil belajar daring siswa.
\end{abstract}

Learning outcomes are not satisfactory and student learning motivation is low. As a result, students cannot fully master the competency of automotive engineering drawings which are learning outcomes.. This study aims to analyze the effect of using autocad software to improve students' online learning outcomes of automotive engineering drawings. This quasi-experimental study used a pretest-posttest design and a control group. All class X students of the engineering and motorcycle business expertise program in two vocational schools became the population in this study. The sample used in this study amounted to 112 students who were divided into 4 classes in two vocational schools. The data collection technique was carried out using tests with multiple choice objective test instruments and drawing worksheets. The collected data were analyzed using descriptive statistics and inferential statistics with $t$ test. The results of the $t$ test obtained $t_{\text {count }}=9.703$ with table at a significance level of $5 \%=1.986$. These results show the value of tcount $>$ ttable, so that it accepts $\mathrm{Ha}$ and rejects H0. Thus it is concluded that the use of autocad software in online learning automotive engineering drawings has a significant effect on improving student online learning outcomes.

This is an open access article under the CC BY-SA license.

Copyright (c) 2021 by Author. Published by Universitas Pendidikan Ganesha.

\section{INTRODUCTION}

The essence of vocational education is to prepare graduates who are ready to work and adaptive to changes that occur (Billett, 2011; Clark \& Winch, 2007). Through learning, the work competencies of students which include cognitive, affective and psychomotor aspects must be taught. Vocational education can be successful if all three competencies can be achieved properly (Sudira, 2017). Various efforts have been made to support a better learning process. Policy recommendations and the development of various interactive media based on applications that have higher efficiency are continuously being made (Gusti et al., 2018; Madyatmadja et al., 2018; Sinaga et al., 2019). However, development must be adjusted to certain learning competencies. Learning automotive engineering drawings is one of the subjects in the automotive department. The learning objective is to provide skills in designing and drawing measurable designs so that they can express intentions and are easily understood by others (Furqon \& Pramono, 2017). Technical drawing competencies in vocational education in the automotive field consist of several complex competencies. These competencies consist of the ability to use tools, understand various types of lines and symbols, construction of 2D and 3D images (Nurtanto, 2016). Media and learning resources for automotive engineering drawings have been developed, ranging from modules, e-modules, animation, and even real media. However, students still have difficulties because the 
competency of automotive engineering drawing is very complex (Aryana et al., 2019). This is shown during the observation activities by researchers. Learning outcomes are not satisfactory and student learning motivation is low. As a result, students cannot fully master the competency of automotive engineering drawings which are learning outcomes.

The problem of learning outcomes of low automotive engineering drawings is exacerbated by the presence of the Covid19 pandemic. Learning that was originally taught offline becomes done online (Onyema et al., 2020). This of course can increase the decline in learning outcomes because practical competence is more effectively carried out offline (Abidah et al., 2020; Stone \& Pate, 2020). Online learning presents challenges to teachers and their development (la Velle et al., 2020). Teachers as learning facilitators are required to be creative to help solve these problems (Rindu \& Ariyanti, 2017). The development and application of interactive media that can support the achievement of practical competencies is an important key (Darmawan \& Khairudin, 2017). The application of technical drawing-based media applications is important to try in order to improve student learning outcomes during the Covid19 pandemic. AutoCAD is a computer aided design application software to help design and design engineering drawings (Sugianto, 2010). AutoCAD has a function for drawing 2dimensional and 3-dimensional objects developed by Autodesk. AutoCAD is a drawing software with a fairly good function that produces graphic documents manifested in graphic rendering automation (Li, 2013). AutoCAD was created to help make it easier and time efficient to create a design drawing that requires high precision and accuracy (Falivene et al., 2019). AutoCAD is commonly used to create technical drawings in the fields of machinery, automotive machinery, and building design (Sugianto, 2010). Thus, AutoCAD is very possible to be applied in learning engineering drawings, one of which is in the automotive field.

The application of AutoCAD software as a learning support medium has effectiveness in improving student learning outcomes (Ziden et al., 2012). The increase in learning outcomes occurred after the application of the software in learning. In addition, the use of AutoCAD in learning can also increase student interest in learning (Ziden et al., 2012). Student interest in learning is very important to improve mastery of learning material, so that it will improve student learning outcomes. In learning automotive engineering drawings, AutoCAD can be applied offline-as well as online. During online learning, the use of AutoCAD is carried out using a teleconferencing platform that is connected to the internet network (Li, 2013). Learning will be carried out in a demonstration by the teacher and followed by students. Of course, online learning on automotive engineering drawings using autocad has its own advantages over offline learning (Priambodo \& Nuryanto, 2020). Time efficiency is an interesting gap that can be used by both teachers and students to study anywhere and anytime ( $\mathrm{Li}, 2013)$.

Based on the above discussion, AutoCAD software can play an important role in overcoming the problems of learning outcomes of automotive engineering drawings of vocational students. The software is feasible to be applied in learning automotive engineering drawings which has the aim of forming skills in designing 2D and 3D images. Thus, it is necessary to conduct research to test whether the autocad software is effective in improving student learning outcomes in online learning automotive engineering drawings. This research is focused on analyzing the effect of online autocad software application on learning automotive engineering drawings in improving student learning outcomes. The research will be conducted in two SMKs with different characteristics, namely State Vocational High Schools and Private Vocational High Schools.

\section{METHOD}

\section{Research design}

The research will be conducted using a quantitative approach using a quasi-experimental design to measure the difference in the effect of the treatment given to certain groups against others under controlled conditions. (Sugiyono, 2017). The research design used involved two sample groups, namely the experimental group and the control group. The two sample groups were given a pretest, treatment and posttest to determine the effect of the treatment given. First, the two groups will be given a pretest to determine the initial ability and ability equivalence between the two groups. Then, the experimental group was given treatment using the autocad application which will be applied as an online learning media for automotive engineering drawings and the control group was given conventional media. Then at the end of the study a post-test was given to the two sample groups.

This study involved research samples taken from the population. The population of this study were all students of class $\mathrm{X}$ of the motorcycle engineering and business expertise program in 2 vocational schools, namely SMK N 1 Seyegan and SMK Muhammadiyah Seyegan with a total of 112 which were divided into 4 classes. In this population, the equivalence test was carried out using the independent sample test to determine the equivalence of all classes by implementing a pretest. The results obtained from the implementation of the equivalence test showed no significant difference in the results of the pretest scores in all classes. The sampling technique used in this study was saturated sampling by using the entire population as the sample (Sugiyono, 
2017). So it was determined that the sample numbered 112 consisting of class X TBSM 1 at SMK N 1 Seyegan and SMK Muhammadiyah Seyegan as an experimental class with a total of 57 students and class X TBSM 2 at SMK N 1 Seyegan and SMK Muhammadiyah Seyegan as a control class with a total of 55 students..

Data collection was carried out using an objective test of automotive engineering drawings to measure learning outcomes at the pretest and post-test. The test instrument contains 25 multiple choice questions and a technical drawing worksheet consisting of pre-treatment (pretest) and after-treatment (postest) test sheets. Instrument validation is done using content validation by asking for expert opinion and using the product moment correlation calculation to measure the validity of the questions. The reliability test was carried out using the formula from Cronbach's alpha to determine the level of consistency of the questions. The results of the validation of the expert opinion state that the pre-test and post-test instruments have high validity. Then the results of the validation of the question items, the significance value of the product moment correlation coefficient is all less than the number 0.05 at the $5 \%$ significance level, so that all the questions in the test are declared valid. The results on the reliability test obtained a reliability coefficient of 0.867 with very high criteria. Thus, the instrument is declared valid and reliable used to collect data.

Data analysis in this study uses descriptive statistics to describe data descriptions and inferential statistics to analyze sample data, and the results are applied to the population. In this study, before testing the hypotheses analyzed by t-test, the analysis prerequisite test was conducted first, which consisted of a normality test and a homogeneity test of variance. The normality test is carried out to determine whether the data is normally distributed or not. To calculate the normality test in this study using the formula from one sample Kolmogorov Smirnov. The variance homogeneity test was used to prove that the data analyzed using the t-test had similar variances. The homogeneity test can be carried out if the two data groups are normally distributed. After the data has passed the prerequisite test, it is followed by hypothesis testing. The alternative hypothesis in this study is "there is a significant difference in the mean learning outcomes between the experimental group and the control group". Hypothesis testing was carried out using independent sample t-test analysis to determine differences in learning outcomes in the post-test between the experimental class and the control class.

\section{RESULT AND DISCUSSION}

The results of data analysis are presented in the description of the data presentation and using the t test results description. Description of the data presentation is carried out to describe a descriptive analysis which includes the mean, middle value, mode, standard deviation, maximum value and minimum value. While the description of the results of the $t$ test is carried out to display the acquisition of $t$ count which is a description of differences in learning achievement. The results of the descriptive analysis of research data, obtained a description of the data from the pre-test and post-test results from the experimental and control classes. The pretest of experimental class results obtained a mean value of 62.55 , a mean value of 62.5 , a mode of 56 , a standard deviation of 4.289, a class minimum score of 56 and a maximum class value of 69 . While, the pre-test of control class results obtained the mean value is 62.65 , the median is 64.00 , the mode is 64.5 , the standard deviation is 4.3242 , the class minimum value is 51 and the class maximum value is 68,5 . Based on these results, it can be explained that the post-tes of experimental class has a mean value of 77.23, median 77,25 mode 71.5, standard deviation 4.1976, the minimum class score of 71,5 and the maximum class value of 84 . Whereas in the post-test of control class had a mean value of 64.59 , a median of 64.5 , mode of 84 , a standard deviation of 5.526, a class minimum score of 53 and a class maximum value of 75.5.

After knowing the results of the descriptive analysis, then the hypothesis testing was carried out to determine the difference in the average learning outcomes in the post-test between the experimental class and the control class. Hypothesis testing is carried out using inferential statistical independent sample t test, which is preceded by the prerequisite analysis test, namely the normality and homogeneity test. The decision-making criteria for the normality test is, if the significance value is $>0.05$, the data is normally distributed. Likewise applies to the variance homogeneity test, decision-making criteria, if the significance value $>0.05$ then the data has the same or homogeneous variance. The results of the normality test using the formula from One sample Kolmogorov Smirnov show that the asymp sig two-tailed value is 0.062 . This result is greater than 0.05 at the $5 \%$ significance level, so it can be concluded that the data is normally distributed. Then, the results of the homogeneity test using one-way ANOVA analysis obtained a significance value of 0.71 . This result is greater than 0.05 at the $5 \%$ significance level, so it can be concluded that the variance of the learning outcome data in the post-test of the experimental and control classes is the same. After it is known that the data is normally distributed and has homogeneous variances, then the independent sample $t$ test is carried out. The independent sample t-test showed the $\mathrm{c}_{\text {ount }}$ of 9,703 with a $\mathrm{p}$ value of 0,000 . The results are then consulted with t table at the $5 \%$ significance level, which is 2.055 . Thus, the $\mathrm{c}_{\text {ount }}$ is greater than $\mathrm{t}_{\text {able }}$ or $\mathrm{t} 9.703>2.055$, so that the alternative hypothesis is accepted or can be concluded that there is a significant difference in learning outcomes between the posttest in the experimental class and the posttest in the control class. 
Based on the results of hypothesis testing, it is known that the alternative hypothesis is accepted or it is concluded that there is a difference in the average learning outcomes in the post-test between the experimental and control classes. The average learning outcomes in the post-test experimental class were significantly higher than the average learning outcomes in the control class post-test. The achievement of learning objectives is determined, among others, by learning outcomes that exceed the minimum completeness criteria (Hamalik, 2014; Ranabumi et al., 2017). Achievement of learning outcomes is one indicator of the effectiveness of learning activities undertaken (Johnson \& Maclean, 2008). The success and effectiveness of learning activities are also characterized by an active, participatory atmosphere based on student-cantered learning (Darling-Hammond et al., 2020; Keiler, 2018). Effective learning activities will ultimately improve the quality and learning outcomes of students, both theory and practice, especially vocational student (Alan et al., 2005; Keiler, 2018). Learning during the Covid-19 pandemic provides opportunities and challenges to carry out the right learning transformation (Liguori \& Winkler, 2020; Toquero, 2020). The transformation of online-based learning is a great opportunity to simulate digital learning for vocational students (Malik, 2018). Online learning also has advantages with flexibility and for students and teachers so that it can be done anytime and anywhere (Anugrahana, 2020). These advantages are what make learning technical drawing online will be effective if it is done using the help of the autocad application software. Having a high level of precision is also an advantage for students. Thus, Autocad is very appropriate in supporting the online learning process of technical drawings that requires a high level of accuracy and precision (Septian \& Handayani, 2017).

Studying technical drawings and understanding through depiction using computers are new to students. Then the interactive application of online subjects can be an effective tool in an effort to increase student interest in learning (Thisgaard \& Makransky, 2017). Practicality in learning technical drawings using software that was not previously known or used by students indicates that students are more interested and motivated to learn new things. Thus, learning outcomes have a great opportunity to be further improved and re-developed (Van Nuland \& Rogers, 2016). The results of this study are supported by research conducted by which concluded. This study strengthens the research which states that there was an increase in student achievement after using autocad software which was applied to learning (Ziden et al., 2012). The results of the research that have been conducted show that learning automotive engineering drawings carried out online using Autocad software has been proven to improve online learning outcomes of class X (ten) students. These results are supported by the results of similar research which states that the implementation of Autocad in learning drawing competencies can improve student learning outcomes (Setyawan \& Munoto, 2016). Based on the research results, Autocad software is suitable for use as a medium to support learning during the Covid-19 pandemic, especially in automotive engineering drawings.

\section{CONCLUSION}

Significant effect of using autocad software in learning to improve student online learning outcomes during the Covid 19 pandemic. This software can be taught online using a virtual face-to-face platform. This learning can also increase students' interest and motivation to learn which will affect the increase in learning outcomes in the end. Thus, autocad software is very suitable for use during online learning, especially in automotive engineering drawing subjects.

\section{REFERENCES}

Abidah, A., Hidaayatullaah, H. N., Simamora, R. M., Fehabutar, D., \& Mutakinati, L. (2020). The Impact of Covid-19 to Indonesian Education and Its Relation to the Philosophy of "Merdeka Belajar." Studies in Philosophy of Science and Education. https://doi.org/10.46627/sipose.v1i1.9.

Alan, C., Saul, E. W., Mathews, S., \& Makinster, J. (2005). Teaching and Learning Strategies for The Thinking Classroom. The International Debate Education Association.

Anugrahana, A. (2020). Hambatan, Solusi dan Harapan : Pembelajaran Daring Selama Masa Pandemi Covid-19 Oleh Guru Sekolah Dasar. Scholaria: Jurnal Pendidikan Dan Kebudayaan, 10(3), 282-289. https://ejournal.uksw.edu/scholaria/article/view/4033.

Aryana, I. G. A., Dewi, L. J. E., \& Nugraha, I. . P. (2019). Pengembangan Media Pembelajaran Berbasis Video Animasi Software Solidworks 2014 Dan Adobe Flash Cs3 Pada Mata Pelajaran Teknologi Dasar Otomotif (Tdo) Materi Motor Bakar. Jurnal Pendidikan Teknik Mesin Undiksha, 7(3), 99-110. https://doi.org/10.23887/jptm.v7i3.26512.

Billett, S. (2011). Vocational Education: Purposes, Traditions and Prospects. Springer. https://doi.org/10.1007/978-94-007-1954-5.

Clark, L., \& Winch, C. (2007). Vocational Education: International Approaches, Developments and Systems. 
Routledge.

Darling-Hammond, L., Flook, L., Cook-Harvey, C., Barron, B., \& Osher, D. (2020). Implications for educational practice of the science of learning and development. Applied Developmental Science, 24(2), 97-140. https://doi.org/10.1080/10888691.2018.1537791.

Darmawan, E. S., \& Khairudin, M. (2017). Development of an Interactive Learning Media to Improve Competencies. 1st International Conference on Technology and Vocational Teacher, 102, 24-27. https://doi.org/10.2991/ictvt-17.2017.5.

Falivene, L., Cao, Z., Petta, A., Serra, L., Poater, A., Oliva, R., Scarano, V., \& Cavallo, L. (2019). Towards the online computer-aided design of catalytic pockets. Nature Chemistry. https://doi.org/10.1038/s41557019-0319-5.

Furqon, Z., \& Pramono, J. (2017). Gambar Teknik Otomotif (Tyas (ed.); II). Penerbit Andi.

Gusti, F. R., Haryadi, H., \& Purnawan, P. (2018). Penerapan Media Interaktif Toleransi Dan Suaian Untuk Meningkatkan Hasil Belajar Siswa Pada Pembelajaran Gambar Teknik. Journal of Mechanical Engineering Education, 5(1), 35-41. https://doi.org/10.17509/jmee.v5i1.12617.

Hamalik, O. (2014). Kurikulum dan Pembelajaran (1st ed.). PT Bumi Aksara.

Johnson, D., \& Maclean, R. (2008). Teaching: Professionalization, Development and Leadership. Springer Science+Business Media B.V.

Keiler, L. S. (2018). Teachers' roles and identities in student-centered classrooms. International Journal of STEM Education. https://doi.org/10.1186/s40594-018-0131-6.

la Velle, L., Newman, S., Montgomery, C., \& Hyatt, D. (2020). Initial teacher education in England and the Covid-19 pandemic: challenges and opportunities. Journal of Education for Teaching, 46(4), 596-608. https://doi.org/10.1080/02607476.2020.1803051.

Li, Y. (2013). Computer aided design based on visual FORTRAN and AutoCAD. In Advanced Materials Research (Vol. 628, pp. 245-248). https://doi.org/10.4028/www.scientific.net/amr.628.245.

Liguori, E., \& Winkler, C. (2020). From Offline to Online: Challenges and Opportunities for Entrepreneurship Education Following the COVID-19 Pandemic. Entrepreneurship Education and Pedagogy, 3(4), 346351. https://doi.org/10.1177/2515127420916738.

Madyatmadja, E. D., Abdurachman, E., Gaol, F. L., Pudjianto, B. W., \& Hapsara, M. (2018). Citizen recommendation for social media-based government application development: A design science $\begin{array}{lllll}\text { approach. Journal of } & \text { Computer }\end{array}$ https://doi.org/10.3844/jcssp.2018.1318.1328.

Malik, R. S. (2018). Educational Challenges In 21st Century And Sustainable Development. Journal of Sustainable Development Education and Research, 2(1), 9-20. https://doi.org/10.17509/jsder.v2i1.12266.

Nurtanto, M. (2016). Interpretasi Gambar Teknik: Mehamami Proyeksi Amerika dan Eropa dengan Mudah dan Penerapan Gambar pada Kelistrikan Otomotif (1st ed.). Parama Publishing.

Onyema, E. M., Eucheria, N. C., Obafemi, F. A., Sen, S., Atonye, F. G., Sharma, A., \& Alsayed, O. A. (2020). Impact of Coronavirus Pandemic on Education. Journal of Education and Practice, 11(13), 108-121. https://doi.org/10.7176/jep/11-13-12.

Priambodo, E., \& Nuryanto, A. (2020). Pengembangan Materi Ajar Berbantuan Edmodo pada Mata Pelajaran Gambar Teknik Manufaktur untuk SMK. Jurnal Dinamika Vokasional Teknik Mesin, 5(2), 145-153. https://doi.org/10.21831/dinamika.v5i2.34803.

Ranabumi, R., Rohmadi, M., \& Subiyantoro, S. (2017). Improving Students' Writing Short Story Skill through Time Token Learning and Video Media. Journal of Education and Learning (EduLearn), 11(4), 439445. https://doi.org/10.11591/edulearn.v11i4.6808.

Rindu, I., \& Ariyanti, A. (2017). Teacher's Role in Managing the Class during Teaching and Learning Process. Script Journal: Journal of Linguistic and English Teaching, 2(1), 83-100. https://doi.org/10.24903/sj.v2i1.77.

Septian, D., \& Handayani, K. D. (2017). Penerapan Model Pembelajaran Kooperatif Tipe Practice Rehearsal Pairs dengan Autocad 3D pada Mata Pelajaran Menggambar Dengan Perangkat Lunak di SMKN 2 Surabaya. Jurnal Kajian Pendidikan Teknik Bangunan, 2, 237-240.

Setyawan, R. B., \& Munoto, M. (2016). Implementasi Model Pembelajaran Langsung Menggunakan Software Autocad pada Kompetensi Dasar Menggambar Rencana Instalasi Penerangan di SMK Raden Patah Mojokerto. Jurnal Pendidikan Teknik Elektro, 05, 951-956.

Sinaga, R. M., Trisnaningsih, T., Pujiati, P., \& Sudarmansyah, D. (2019). Development of Learning Media Based on Mobile Learning Applications. Jurnal Pendidikan Progresif, 9(1), 50-58. https://doi.org/10.23960/jpp.v9.i1.201907.

Stone, J. K., \& Pate, A. N. (2020). The impact of COVID-19 through the eyes of a fourth-year pharmacy student. American Journal of Pharmaceutical Education. https://doi.org/10.5688/ajpe8146. 
Sudira, P. (2017). Tvet Abad XXI: Filosofi, Teori, Konsep, dan Strategi Pembelajaran Vokasional. UNY PRESS.

Sugianto, M. (2010). Merancang Perkantoran dan Perumahan Menggunakan Autocad (I). Penerbit Andi.

Sugiyono. (2017). Metode Penelitian Kuantitatif, Kualitatif, dan R\&D. Alfabeta.

Thisgaard, M., \& Makransky, G. (2017). Virtual learning simulations in high school: Effects on cognitive and non-cognitive outcomes and implications on the development of STEM academic and career choice. Frontiers in Psychology. https://doi.org/10.3389/fpsyg.2017.00805.

Toquero, C. M. (2020). Challenges and Opportunities for Higher Education amid the COVID-19 Pandemic: The Philippine Context. Pedagogical Research, 5(4), 1-5. https://doi.org/10.29333/pr/7947.

Van Nuland, S. E., \& Rogers, K. A. (2016). The anatomy of E-Learning tools: Does software usability influence learning outcomes? Anatomical Sciences Education. https://doi.org/10.1002/ase.1589.

Ziden, A. A., Zakaria, F., \& Othman, A. N. (2012). Effectiveness of AutoCAD 3D Software as a learning support tool. International Journal of Emerging Technologies in Learning, 7(2), 57-60. https://doi.org/10.3991/ijet.v7i2.1906. 